\title{
Die godsdienswetenskaplike aspek van teologie
}

\author{
PJ van der Merwe
}

\begin{abstract}
Religio-scientific aspects of theology

Theology cannot pronounce the science of religion an irrelevant matter, as that would amount to an indifference regarding the missionary task, on the one hand, and on the other hand would demonstrate ignorance regarding its own nature. Theology is being practised in the area between faith and science. Theology consists of the reflexion of faith and religio-scientific investigation finely balanced. Reflexiveness, a radicalizing of reflectiveness, entails that theology will acknowledge this and explore its implications. Confessional theology must provide for a 'theological science of religion' within its ranks.
\end{abstract}

Daar is twee basiese redes waarom die godsdienswetenskap moeilik tot ' $n$ indifferente saak vir die teologie verklaar kan word. Eerstens spreek dit vanself dat daar in die teologiese ensiklopedie ' $n$ vak moet wees waar die verskynsel godsdiens en godsdienstige verskynsels teoreties en teologies verdiskonteer word. Dat so 'n vak of onderdeel daarvan op een of ander wyse by die godsdienswetenskap moet aansluit, lyk ook vanselfsprekend.

Die missionêre dimensie van die teologie noop hom om behoorlik van die wêreld van nie-Christelike godsdienste kennis te neem. Dit impliseer 'n theologia religionum, wat op sy beurt na 'n theologia religionis teruggevoer moet kan word.

Verder kan gesê word dat die godsdienstige bewussyn en hunkering van mense een van die vernaamste kenmerke is van die wêreld waarbinne kerk en teologie leef en optree en dat 'n behoorlike kennisname van die adres aan wie die verkondiging gerig is, die verstaan van die godsdiens insluit.

Die vraag na die uniekheid en aard van die Christelike geloof in vergelyking met ander godsdienste en godsdienstige verskynsels maak ook so ' $n$ vak noodsaaklik. Aangesien dit moontlik is om belangrike ooreenkomste tussen die Christelike godsdiens en nie-Christelike godsdienste aan te toon, is dit duidelik dat hierdie saak nie ligtelik hanteer kan word nie. 'n Theologia religionis waarin ook hieroor gehan- 
del word, is dus 'n onvermydelike rubriek in die teologiese ensiklopedie.

Die tweede basiese rede waarom die godsdienswetenskap vir die teologie nie 'n irrelevante saak kan wees nie, is dat die teologie self ' $n$ godsdienswetenskaplike aspek vertoon.

Teologie word beoefen in die area tussen godsdiens en geleerdheid. Teologie behels geloofsdenke, waardeur dit terugknoop aan geloof en 'n bepaalde godsdienstige tradisie, maar dieselfde geloofsdenke verbind dit ook aan die tradisie van geleerdheid wat binne dieselfde kultuurwêreld funksioneer. Binne die homolitiese leefwêreld lê godsdiens en geleerdheid so na aan mekaar dat teologie bykans nie as sodanig te identifiseer is nie.

Binne ons Westerse leefwerreld wat byna tot die punt van atomisering gedifferensieer is, is dit egter heeltemal anders. Geleerdheid het as gesekulariseerde wetenskap ontwikkel, met sekere metodologiese beginsels wat dit in sommige belangrike opsigte in spanning bring met geloof en godsdiens in die algemeen.

Genoemde metodologiese beginsels kan oorsigtelik soos volg aangedui word:

- Die strewe na objektiwiteit en die eis dat die wetenskaplike onpartydig in werk en oordeel moet wees.

- Die kritiese en skeptiese ingesteldheid van die wetenskaplike.

- Die eis dat resultate in beginsel vir en deur enige persoon toeganklik en herhaalbaar moet wees.

- Die verifikasie-eis met sy sterk empiriese inslag.

- Die norm van logiese konsistensie met sy rasionalistiese ondertone.

Die feit dat teologie in die gebied tussen godsdiens (insluitend geloof) en wetenskap beoefen word, verklaar veel van die spanning en metodologiese dilemmas wat deur die teoloog ervaar word en wat herinner aan die spanning tussen die nuwe en oue mens van Romeine 7 . Die teoloog dra in hom die momente van beide wetenskaplike en gelowige. Ten spyte van vele pogings om 'n harmonie tussen wetenskap en geloof te bewerk, bly dit twee wêrelde wat moeilik harmonieer. Om terug te keer na die oorsig van metodologiese beginsels....

Die teologie vereis self ' $n$ bepaalde objektiwiteit en wetenskaplike onpartydigheid, naas eksistensiële en geloofsbetrokkenheid. Dit beteken dat die teoloog enersyds die rol van 'n gedistansieerde analitikus, waarnemer en verklaarder moet speel en andersyds as normatiewe en kreatiewe geloofsdenker te werk moet gaan. 
Veel moeiliker nog is die wetenskaplike kritiese ingesteldheid, soos onder andere gesuggereer in terme soos 'tekskritiek' en 'redaksie-kritiek', te harmonieer met die gesindheid van kinderlike geloofsaanvaarding wat geloofsdenke veronderstel.

Teologiese resultate is slegs tot 'n sekere mate vir enigeen toeganklik en herhaalbaar. ' $n$ Verdere deel daarvan funksioneer op die vlak van die algemeen Christelik-gelowige en nog 'n verdere deel op die vlak van diegene wat in die bepaalde Christelike geloofstradisie ingewy is en daaraan deel het. Aan die ander kant kan hierdie wetenskaplike beginsel nie geminag word nie, omdat dit verband hou met een van die vernaamste verskille tussen geloofsdenke en teologie. Dit verklaar waarom die teoloog tot op 'n sekere hoogte met teoloë uit ander tradisies en selfs kundiges op ander terreine kommunikeer en daar 'n uitruiling van idees en insigte tussen hulle kan plaasvind.

Oor die verifieerbaarheid van teologiese stellings en resultate is heelwat geskryf. Hierdie saak hou direk verband met die vorige. Teenoor die standpunt dat die teologiese uitsprake op die vlak van die affektiewe lê en verifikasie dus irrelevant is, staan die teologie oor die algemeen op die standpunt dat dit op die kognitiewe vlak ook funksioneer en verifikasie in beginsel tog ter sake is. J Hick noem die moontlikheid van eskatologiese verifikasie. Vir die empiristiese verifikasiebeskouing is dit nie juis aanvaarbaar nie, maar aan die ander kant funksioneer die empirisme veel sterker in die natuur- as in die geesteswetenskap. Dit is nogtans so dat die verifikasie-eis 'n mate van interne spanning in die teologie skep.

Op die eis van logiese konsistensie sê die teologie beide ja en nee. Sonder logiese en kommunikatiewe konsistensie kan teologie kwalik bokant die vlak van mistiese meditasie uitstyg. Aan die ander kant vloei daar 'n aantal logiese dilemmas uit die geloofsinhoud voort wat die teologie nie kan minimaliseer of ignoreer nie, omdat hulle die knooppunte uitmaak wat die netwerk van geloofsbeginsels aan mekaar hou.

Die spanning en interne dilemmas van die teologie is in die laaste instansie terug te voer na menslike denke en onderskeidingsvermoë, enersyds, wat hom rig op goddelike geopenbaarde waarheid wat eintlik alle menslike begrip en insig te bowe gaan, andersyds. Uiteraard word veronderstel dat hierdie menslike denke en onderskeidingsvermoë dié is van 'n bekeerde en wedergebore mens wat verder ook nog deur die werkinge van die Gees verlig word. Paulus getuig egter dat hierdie gelowige mens nie net 'n nuwe mens is nie. Hy is ook nog oue 
mens solank hy aan die duskant van die graf en die voleinding lewe. Die geloof lei hom om te aanvaar wat hy verstandelik nie kan peil nie en om oor logiese dilemmas heen na die heilswaarhede te kyk. Hy bly egter steeds aan menslike logika en denkvermoë gebind en dit is hierdie selfde menslike logika en denkvermoë wat hom met geleerdheidsen wysheidtradisies van sy leef- en kultuurwêreld verbind. Hiervan het ons verskeie voorbeelde uit die Bybel en vroeë kerk. Vir die insig wat alle teenstrydighede sal opklaar, wag die teologie saam met die kerk en alle gelowiges op die voleinding. Teologie is tussentydelike aktiwiteit en moontlik een van die duidelikste aanduidings dat die voleinding nog nie aangebreek het nie.

Aan die ander kant sou dit verkeerd wees om dit wat tot dusver oor teologie gesê is, so op te neem asof dit 'n skisofreniese aktiwiteit is waar die wetenskaplike en gelowige in die teoloog binne ' $n$ dualistiese worstelstryd vasgevang is. Teologie word altyd uit die geloof onderneem en geloof bly altyd ook die motivering (fides quaerens intellectum). Dieselfde geloof behoed die teoloog van skisofrenie deurdat dit hom voortdurend herinner aan die beperktheid van menslike insig en oordeelsvermoë en teruglei na die liefde van God waarin onrustigheid en stryd tot rus kom.

In die geval van moderne Westerse teologie word genoemde spanning in skerper reliëf ervaar deurdat geleerdheid in die gestalte van gesekulariseerde wetenskap verskyn. Die moontlikheid dat die Westerse teologie hom van die wetenskap kan losmaak, kan amper nie eers teoreties oorweeg word nie. Die ontwikkeling van 'n gesekulariseerde wetenskap en aanverwante tegnologie kan waarskynlik onder andere na Christelike invloed teruggevoer word en is dus nie iets waarop kerk en teologie sonder meer die rug kan keer nie. Nie alleen is die teoloog self iemand wat in hierdie kennistradisie opgegroei het en gevorm is nie, maar vir sover die teologie dienstig is aan die verkondigingstaak van die kerk, geld die plig van inheemswording ook vir kerk en teologie in die Weste. Die Westerse kultuurwêreld is nie los te dink van die tradisie van gesekulariseerde wetenskap nie. (Inheemswording beteken uiteraard nie assimilasie nie.)

Namate die area tussen wetenskap en godsdiens groter geword het, het die spektrum van moontlike posisies in die gebied ook wyer geword. Die uiterste posisie na die wetenskaplike kant word verteenwoordig deur die godsdienswetenskap en dié na die godsdienstige kant deur geloofsmeditasie. Hoe nader teologie aan sy godsdienstradisie (en tegelyk verder weg van die wetenskap) beoefen word, des te 
meer word dit geloofsmeditasie en teologiese opleiding gelyk aan gevorderde kategese. Hoe nader teologie aan die wetenskap beoefen word, des te meer word dit godsdienswetenskap, en teologiese opleiding gelyk aan (godsdiens-)wetenskaplike opleiding. Dit is duidelik dat teologie nie net godsdienswetenskap of net geloofsmeditasie kan wees nie, gewoon omdat nie een van die twee as sodanig teologie is nie. Met vrymoedigheid kan gesê word dat alle (Westerse) teologie een of ander balans van godsdienswetenskap en geloofsdenke uitmaak.

So ' $n$ stelling kan maklik bevestig word as nagegaan word hoeveel van wat in die teologie gedoen word, net so wel in die godsdienswetenskap sou kon plaasvind en inderdaad ook plaasvind.

Tekskritiek, literatuuranalise, redaksiekritiek en vele ander metodes wat in die Bybelvakke toegepas word, kan ewe goed deur ' $n$ godsdienswetenskaplike toegepas word in sy bestudering van die Koran, die Oepanisjads of die Talmoed. Baie van die literatuurteorieë waarmee daar vandag in die Bybelse hermeneutiek gewerk word, is van buiteteologiese oorsprong. Aan die ander kant is die godsdienswetenskap veel aan die teologie verskuldig vir eksegetiese prosedures wat deur teoloë ontwikkel en verfyn is.

Die historiese metodes en historiese metode-benaderings wat in die teologie toegepas word, veral in die kerkgeskiedskrywing, verskil kwalik van dié wat in sekulêre geskiedskrywing of godsdiensgeskiedenis toegepas kan word.

Sistematisering, eksplisering en spekulatief-kreatiewe denke soos dit dwarsdeur die teologie, maar veral in dogmatiek en etiek toepassing vind, vind ' $n$ mens uiteraard ook in die godsdienswetenskap, veral in die godsdiensfilosofie of fundamentele godsdienswetenskap.

Dit sou egter ' $n$ foutiewe afleiding wees dat hiermee te kenne gegee word dat daar nie 'n wesenlike verskil tussen godsdienswetenskap en teologie is nie. Kortliks gestel is die godsdienswetenskaplike ' $n$ onbetrokke waarnemer en die teoloog iemand wat in die laaste instansie eksistensieel betrokke is by die geloofstradisie waarmee hy besig is. Die vraag kan natuurlik gevra word of die godsdienswetenskaplike heeltemal onbetrokke en objektief is, maar dit is ' $n$ debat waarop ons nie nodig het om in te gaan nie. Die doel van hierdie besinning is immers nie om die teologiese aspek van godsdienswetenskap te verken (indien daar wel so iets sou bestaan) nie.

Ten spyte van die klaarblyklike verband tussen teologie en godsdienswetenskap, asook die betekenis van godsdienswetenskap vir die teologie, bestaan daar 'n mate van twyfel en verleentheid oor hoe dit in 
die teologiese ensiklopedie en opleiding verdiskonteer moet word. Ons wil vervolgens verwys na vier modelle waarvolgens die saak hanteer kan word.

Tradisioneel bestaan daar ' $n$ mate van spanning in die verhouding tussen ' $n$ sekere deel van die kontinentale Protestantse teologie en godsdienswetenskap. Dit kan teruggevoer word na die rasionalistiespositiwistiese oorspronge van die godsdienswetenskap. Verder het Barth in sy vete met die theologia naturalis daarin geslaag om die posisie van die godsdienswetenskap aan die teologiese fakulteit onder 'n vraagteken te stel. Saam met nuwe sienswyses wat binne die godsdienswetenskap oor die taak en doel daarvan ontwikkel het, het dit daartoe gelei dat die vak in vele gevalle oorgeskuif het na die Fakulteit Lettere en Wysbegeerte. Dit is dan ons eerste model: teologie en godsdienswetenskap bestaan in afsondering van mekaar. Hierdie model openbaar die leemte dat die teologie afgesny kan word van die godsdienswetenskaplike denke oor verskeie sake wat vir die teologie van betekenis is.

Die tweede model is wanneer godsdienswetenskap as 'n departement van teologie funksioneer, maar daar geen poging aangewend word om die vak met die teologiese geheel te integreer nie. Hierdie situasie hou praktiese voordele bo die eerste in, maar is prinsipieel minder bevredigend.

Die derde model is die wat in die Engelse wêreld ontwikkel het, te wete 'n department of religious studies binne die Fakulteit Lettere en Wysbegeerte. Volgens hierdie model maak die godsdienswetenskap die oorkoepelende raamwerk uit waarbinne enige teologie (Christelik, Moslem, Hindoe) ingepas of beoefen kan word. Dit beteken onder andere dat ' $n$ bepaalde visie van godsdiens as omvattende konsep geld waarbinne die verskillende godsdienste 'van buite af' ingepas word en die Christelike teologie so in 'n Procrustesbed ingedwing mag word. Die basiese eksklusiwiteitsaansprake van die Christelike teologie (en die meeste ander godsdienste) word ook enigermate gekompromitteer. Dit spreek vanself dat hierdie model uit owerheidsoogpunt praktiese voordele inhou, maar uit die oogpunt van 'n belydende teologie is daar min aantreklikheid daarin.

Die vierde en laaste model is die waar die godsdienswetenskap in 'n egte teologiese vak omskep word en so in die teologiese ensiklopedie ingepas word. Dit verskil van die deskriptiewe, geesteswetenskaplike godsdienswetenskap (wat nog steeds in die Fakulteit Lettere en Wysbegeerte kan bestaan) daarin dat die evaluatiewe en normatiewe 
denke wat laasgenoemde moet vermy, 'n integrale deel daarvan is. Die waardes wat daarin funksioneer, is dieselfde as wat in die res van die teologie funksioneer.

Laasgenoemde model is uiteraard die mees aanvaarbare reëling in die geval van teologiese fakulteite met 'n sterk belydende inslag. Die nuttigheidswaarde van so ' $n$ vak vir die praktyk-gerigte deel van die teologie, soos praktiese teologie en sendingwetenskap, spreek vanself: Hierdie vakke word gehelp om die verskynsels van die wêreld waarop hulle gerig is, te verstaan. Dit het egter ook groot waarde vir die hele teologie, naamlik dat dit die teologie in sy kritiese selfrefleksie kan bystaan.

Teologiese selfrefleksie het te doen met wat Krüger (1982) 'refleksiewe denke' noem, die hoogste vorm van metodologiese bewussyn. Hy beskryf dit soos volg: 'A useful term for the kind of activity where the investigator investigates himself as investigator, is reflexiveness. This self-analysis may be distinguished from two other types of knowing activity. The first of these is unreflectiveness, which refers to our normal everyday way of dealing with the world, where we take things for granted. A second type is reflectiveness. The knower experiences a distance between himself and the normal things. They become problematic. This may be the beginning of the scientific (theoretical) kind of knowing, which refers to the way of dealing with the world (in our case, with religion), as we partly describe it in this introduction. The concept reflexiveness ... has to do with the kind of investigation where the knower turns back on himself in his act of knowing. It is thus a special form, an expansion, a radicalizing of reflectiveness. The student of religion here heeds himself. He follows, as it were, in his own tracks, made as he moves around in his world as an everyday man, a religious man, or as a student of religion' (Krüger 1982:44).

Refleksiewe denke is 'n plig wat op die teologie as wetenskap, sowel as geloofsdenke, rus. Die evangeliese kritiek verg hierdie radikale openhartige eerlikheid. Dit is 'n plig wat op elke vak van die teologie neerkom. Op die 'teologiese godsdienswetenskap' rus dit egter op 'n besondere wyse. 'n Groot deel van die weefdrade van die teologie steek in hierdie vak uit, vanweë die godsdienswetenskaplike aspek van elke teologiese vak. Daarbenewens staan die vak so half op die rand van die teologie, sodat dit nie alleen 'n geheelvisie op die teologie het nie, maar ook nog op effe gedistansieerde wyse daarop kan uitkyk. Hierdie posisie van die teologiese godsdienswetenskap bring ook mee dat dit die groothede buite die geloof wat die meeste invloed op teologie uitoefen, 
voortdurend in sy visier kan hou, naamlik godsdiens as menslike verskyningsvorm en geleerdheid. Beide hierdie groothede kan op hulle beurt as kulturele verskyningsvorme gekarakteriseer word, sodat 'teologiese godsdienswetenskap' in hierdie opsig op kultuurkritiek neerkom.

'n Teologie wat 'n refleksiewe bewussyn ontbeer, is byvoorbeeld een wat in salige onkunde oor religieuse en filosofies-ideologiese ondertone in sy eie tradisie en beoefening verkeer. Dit kan reflektief wees, dit wil sê, een stap weg wees van 'n naïwe, onkritiese mentaliteit. Dit kan egter kwalik oor daardie soort kritiese onderskeidingsvermoë beskik wat die teologie nodig het om die kerk en sy verkondiging in die wêreld waarlik diensbaar te wees. Beter teologie beteken nie 'n opgeblase teologie nie, maar juis een wat in nederige bewussyn van sy beperkinge beoefen word.

\section{Literatuurverwysing}

KRÜGER, JS 1982. Studying religion: A methodological introduction to science of religion. Pretoria: Unisa. 